Tropical Journal of Pharmaceutical Research December 2015; 14 (12): 2193-2200

ISSN: $1596-5996$ (print); 1596-9827 (electronic)

(c) Pharmacotherapy Group, Faculty of Pharmacy, University of Benin, Benin City, 300001 Nigeria.

All rights reserved.

Available online at http://www.tjpr.org http://dx.doi.org/10.4314/tjpr.v14i12.6

Original Research Article

\title{
Artificial Synthesis of Conserved Segment S Gene Fragment of Rift Valley Fever Virus and Preliminary Study of Its Reverse Transcription Loop-Mediated Isothermal Amplification Detection Method
}

\author{
Zexiao Yang ${ }^{1}$, Guili Li ${ }^{1}$, Yihong Hou ${ }^{2}$, Xueping Yao', Ranyang Ren ${ }^{1}$, Houxun \\ $\mathrm{Ya}^{1}$, Shanzhen Peng ${ }^{1}$, Xingyu Lin ${ }^{1}$ and Yin Wang ${ }^{1}$ \\ ${ }^{1}$ College of Veterinary Medicine, Sichuan Agricultural University, Yaan 625014, ${ }^{2}$ Changde Entry-Exit Inspection and Quarantine \\ Bureau, Changde 415100, China
}

${ }^{*}$ For correspondence: Email: yzxyang2003@126.com; Tel: +86-083502885077; Fax: +86-083502885077

Received: 21 June 2015

Revised accepted: 26 October 2015

\begin{abstract}
Purpose: To develop a rapid detection method for Rift Valley fever virus (RVFV) diagnosis. Methods: According to the reference sequences of RVFV published in GenBank, nine overlapping polymerase chain reaction (PCR) primers and four specific reverse transcription loop-mediated isothermal amplification (RT-LAMP) primers were designed using DNAStar and LAMP primer design software, respectively. Based on the synthesis of a conserved part of the RVFV $S$ segment gene sequence using overlapping PCR, RT-LAMP assay was first established and evaluated after a series of tests, including, optimization of reaction conditions, and sensitivity and specificity tests.

Result: A target RVFV S segment gene fragment of $288 \mathrm{bp}$ was synthesised. The optimal reaction conditions for RT-LAMP assay were $63{ }^{\circ} \mathrm{C}$ for $45 \mathrm{~min}$ : the assay has a specific ladder-like pattern of amplification bands from about $120 \mathrm{bp}$. The lowest target gene copy number of RT-LAMP for RVFV detection was 70 copies. The assay showed good specificity as only the synthesised target RVFV gene was amplified with no amplification for the detection of Peste des petits ruminants virus, Epidemic encephalitis B virus, E. coli, Pasteurella multocida, or Salmonella.

Conclusion: This study provides a rapid, sensitive, specific RT-LAMP method for RVFV detection.
\end{abstract}

Keywords: Rift valley fever virus, Overlapping polymerase chain reaction, Reverse transcription loopmediated isothermal amplification, Rapid diagnosis test

Tropical Journal of Pharmaceutical Research is indexed by Science Citation Index (SciSearch), Scopus, International Pharmaceutical Abstract, Chemical Abstracts, Embase, Index Copernicus, EBSCO, African Index Medicus, JournalSeek, Journal Citation Reports/Science Edition, Directory of Open Access Journals (DOAJ), African Journal Online, Bioline International, Open-J-Gate and Pharmacy Abstracts

\section{INTRODUCTION}

Rift Valley fever (RVF), resulting from the RVF virus (RVFV), is an acute and febrile infection of both ruminants and humans [1]. It was first found in the Great Rift Valley in Kenya in 1930 [1]. Animals such as sheep, goats, and cattle are the species mostly affected by the infection. Epidemics are characterized by the occurrence of fever, blood diarrhea, and abortion in pregnant animals. When infected by RVFV, pregnant dams show an abortion rate of $90-100 \%$. The mortality rate for adult animals of different species varies in the range 10 to $60 \%$, and that of newborn lambs reaches $90-100 \%$ [2-4]. Humans infected by the virus have moderate symptoms such as chills, headache, and pain in the extremities (that is, influenza-like symptoms) or there may be other unapparent symptoms. Infection usually lasts for several days and may 
lead to retinal injury, temporary or permanent blindness, encephalitis, hemorrhagic hepatitis, and, in serious cases, even death [2-5]. Heavy economic losses have been inflicted on countries and areas as a result of RVF epidemics and the threat to human health posed by RVF is serious as well. RVF has now become officially notifiable to the International Epizootic Office (OIE), and is listed in category $A$ of the directory of animal diseases [1]. RVFV is an RNA virus in the genus Phlebovirus (family Bunyaviridae); its virions are spherical, enveloped, and $90-110 \mathrm{~nm}$ in size [1]. Although RVFV shows common resistance to the outside environment, it presents strong transmission capability. It can be transmitted by aerosol, touch, or consumption of infected animal tissue, and vertically via the placenta, as well as by mosquito bites [5-7]. As a result of the broad range of transmission modes, and also for climatic and geographical reasons, RVFV attacks occur periodically with high frequency and are difficult to control. RVFV is a typosis in some African countries and areas, but has spread to areas of the Mediterranean coast and Middle East, showing its potential to spread to areas outside of Africa [1]. Previous reports have indicated that RVFV has been isolated in from over 30 mosquito species [5] of mosquito. As these mosquitoes are distributed around the world, RVFV is prone to spread to Europe, America, and other non-epidemic areas [5,8-10]. Indeed, with the development of international trade in animal and animal products, population migration, and climate change, the risk of RVFV spreading increases continually. Due to the fact that there are no efficient vaccines for humans or animals [5], controlling and conducting research on RVF have becoming more urgent and significant.

Since RVFV infections do not currently occur in China, preventing the transmission of RVFV by studying RVFV control (especially rapid diagnosis technology) has great significance for public health. Loop-mediated isothermal amplification (LAMP), as a new nucleic acid amplification technology, presents high specificity and sensitivity, and has low equipment requirements for reaction, reading, and judgment. The amplification results are likely to read and judge by directly observing the variation in turbidity (resulting from the white precipitate of magnesium pyrophosphate) using the naked eye. Due to these advantages, LAMP has become a new and important research direction for the detection and diagnosis of many pathogens $[11,12]$.

\section{EXPERIMENTAL}

\section{Materials}

$2 \times$ Taq PCR Master Mix, Betaine (Z0041-1), DNA Marker DL 2000 (D501A), pMD19-T Vector, Pfu DNA polymerase, EcoR I(K2153BA), Primerscript RT reagent Kit (BK1901), and RNAiso Plus were purchased from TaKaRa (Japan), Bst polymerase (M0275) was obtained from Beijing New England Biolabs Co. Ltd., Peste des petits ruminants virus (live vaccine), epidemic encephalitis B virus (inactivation vaccine), Pasteurella multocida, E. coli, and Salmonella were provided by the animal quarantine Laboratory of Sichuan Agricultural University.

\section{Design and preparation of primers}

Based on the sequence of conserved segment $S$ gene fragments of RVFV (accession no. HE687307), nine overlapping oligo primers and four specific primers for RT-LAMP (Table 1) were designed using DNAStar and Primer Explorer V4 software (http://primerexplorer.jp/e/), respecttively. All of these primers were prepared by TaKaRa Biotechnology (Dalian) Co., Ltd, and diluted to their working concentrations with double distilled $\mathrm{H}_{2} \mathrm{O}$ (dd $\mathrm{H}_{2} \mathrm{O}$ ) for subsequent tests.

\section{In vitro synthesis of target RVFV segment S gene fragments}

The conserved sequence fragment of the RVFV segment $\mathrm{S}$ gene (target DNA) was synthesised in vitro using an overlap extension PCR method and was then cloned into the pMD9-T vector to construct the recombinant plasmid (named pMD19-T-RS) as described elsewhere [12,13].

For the primary extension procedure, a $50 \mu \mathrm{L}$ reaction volume containing $5 \mu \mathrm{L} 10 \times$ Pfu DNA polymerase buffer, $6 \mu \mathrm{L}$ of dNTPs $(2.5 \mathrm{mmol} / \mathrm{L}$ of each nucleotide), $1 \mu \mathrm{L}(10 \mu \mathrm{mol} / \mathrm{L})$ of each of the overlapping oligo primers (F1/R1, F2/R2, or F3/R3), $1 \mu \mathrm{L}$ of Pfu DNA polymerase, and $36 \mu \mathrm{L}$ $\mathrm{ddH} 2 \mathrm{O}$ were used. The reaction conditions were $94{ }^{\circ} \mathrm{C}$ for $30 \mathrm{~s}$, and $72{ }^{\circ} \mathrm{C}$ for $15 \mathrm{~min}$. Secondary extension reactions were then carried out until the full-length target DNA fragment product had been synthesised in the $50 \mu \mathrm{L}$ volume reaction including $1 \mu \mathrm{L} 10 \times$ Pfu DNA polymerase buffer, $6 \mu \mathrm{L}$ of dNTPs, $1 \mu \mathrm{L}$ of Pfu DNA polymerase, and $21 \mu \mathrm{L}$ of each of the two overlapping primary/previous extension reaction products. 
Table 1: Primers used for study of RVFV RT- LAMP detection

\begin{tabular}{|c|c|c|}
\hline $\begin{array}{l}\text { Task and Primer } \\
\text { name }\end{array}$ & Sequence (5'-3') & $\begin{array}{l}\text { Product } \\
\text { size }\end{array}$ \\
\hline \multicolumn{3}{|l|}{ Overlapping PCR } \\
\hline P1 & ACCATCGTCCTAGTCACGAG & \multirow[t]{8}{*}{$288 \mathrm{bp}$} \\
\hline $\mathrm{P} 2$ & TCTGATCCCTTCTAATGTCAT & \\
\hline $\mathrm{F} 1$ & $\begin{array}{l}\text { TCGTCCTAGTCACGAGGTTCGCTTGCGATTTTCTGATTTCTACAATGTCGG } \\
\text { AGAATTCC }\end{array}$ & \\
\hline F2 & $\begin{array}{l}\text { TCAAACGTTGCACCTCCACCAGCAAAGCCTTTCCAGAGACTTATTGATCTA } \\
\text { ATAGGCCA }\end{array}$ & \\
\hline F3 & $\begin{array}{l}\text { CCAATCTAAAAGAAGCCATATCCTGGCCTCTTGGAGAACCCTCACTAGCT } \\
\text { TTCTTTGAC }\end{array}$ & \\
\hline R1 & $\begin{array}{l}\text { AGGTGCAACGTTTGATGCAAAGTCTCCAAGTCCGACTCGGTATGGGAATT } \\
\text { CTCCGACAT }\end{array}$ & \\
\hline $\mathrm{R} 2$ & $\begin{array}{l}\text { CTTCTTTTAGATTGGGGAACCTTGTGAAATCACTAAGAGTCATATGGCCTA } \\
\text { TTAGATCA }\end{array}$ & \\
\hline R3 & $\begin{array}{l}\text { TCCCTTCTAATGTCATCATTCCTGTGCACTCTAGTAGAGCTTAGGTCAAAG } \\
\text { AAAGCTAG }\end{array}$ & \\
\hline RT-LAMP & & \\
\hline $\begin{array}{l}\text { F3 } \\
\text { B3 }\end{array}$ & $\begin{array}{l}\text { CGCTTGCGATTYTCTGAT } \\
\text { GCTTCTTTYAGATTGGGGAAC }\end{array}$ & 173 bp \\
\hline FIP & GCAACGTTTGATRCAAAGTCTCTTCTACAATGTCGGAGAATTCC & $120-b p$ \\
\hline BIP & CCTCCACCAGCRAAGCCTTTCTTGTGAAATCACTAAGAGTCAT & \\
\hline
\end{tabular}

The reaction conditions were kept the same as those described for the aforementioned primary extension procedure.

The full-length target DNA fragments, from the previous secondary extension reaction, were amplified by PCR using primers $\mathrm{P} 1$ and $\mathrm{P} 2$ in a $50 \mu \mathrm{L}$ reaction volume containing $25 \mu \mathrm{L} 2 \times$ Taq PCR Master Mix, $1 \mu \mathrm{L}(10 \mu \mathrm{mol} / \mathrm{L})$ of each of the primers (P1 and P2), $3 \mu \mathrm{L}$ of template (full-length

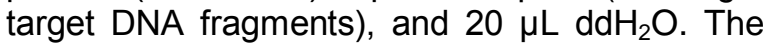
PCR was conducted as follows: denaturing at 95 ${ }^{\circ} \mathrm{C}$ for $5 \mathrm{~min}$; followed by 30 cycles at $94^{\circ} \mathrm{C}$ for $40 \mathrm{~s}, 56{ }^{\circ} \mathrm{C}$ for $40 \mathrm{~s}$, and $72{ }^{\circ} \mathrm{C}$ for $45 \mathrm{~s}$; the procedure was then terminated by an elongation at $72{ }^{\circ} \mathrm{C}$ for $8 \mathrm{~min}$. Some $5 \mu \mathrm{L}$ of PCR product was analysed in a $10 \mathrm{~g} / \mathrm{L}$ agarose in TAE buffer gel containing $0.5 \mathrm{mg} / \mathrm{mL}$ GreenView through electrophoresis, which was then photographed under a UV imaging system (Bio-Rad).

The PCR products were subsequently separated and purified according to the TIANgel Midi Purification Kit (DP209) instructions: they were then directly cloned into the pMD19-T Vector followed by a transformation into $\mathrm{DH} 5 \mathrm{a}$ competent cells. Then, the recombinant plasmids were extracted using a TIANprep Mini Plasmid Kit, and were subsequently identified by PCR (using P1/P2 and RV-M/M13-47 as primers) and sequencing analysis [13].

\section{RVFV Basic RT-LAMP reaction}

The RT-LAMP reaction mixture (25 $\mu \mathrm{L})$ contained $2.5 \mu \mathrm{L}$ of $10 \times$ ThermoPol buffer, $1 \mu \mathrm{L}$ (8 units) of BstDNA polymerase, $3 \mu \mathrm{L}$ of $\mathrm{MgCl}_{2}$
(25 mM), $3 \mu \mathrm{L}$ of betaine $(8 \mathrm{mM}), 8 \mu \mathrm{L}$ of dNTP $(2.5 \mathrm{mM}), 1 \mu \mathrm{L}$ of each of the primers (F3 $(5 \mu \mathrm{M})$, B3 $(5 \mu \mathrm{M})$, FIP $(50 \mu \mathrm{M})$, and BIP $(50 \mu \mathrm{M})), 1 \mu \mathrm{L}$ of template (the recombinant plasmids), and 2.5 $\mu \mathrm{L}$ of $\mathrm{ddH}_{2} \mathrm{O}$. The reaction mixture was incubated at $65^{\circ} \mathrm{C}$ for $1 \mathrm{~h}$ then heated at $80^{\circ} \mathrm{C}$ for $2 \mathrm{~min}$ in a water bath (DSY21-8, China): the amplified products were analysed in a $15 \mathrm{~g} / \mathrm{L}$ agarose in TAE buffer gel. The results could also be seen by the naked eye because of either the white precipitate of magnesium pyrophosphate generated in the reaction, or the green colour change under $254 \mathrm{~nm}$ wavelength UV light upon the addition of diluted SYBR Green I (3280-50, TIANDZ, China). To confirm the specificity of amplification products, $10 \mu \mathrm{L}$ of the reaction mixture was digested with EcoR I at $37^{\circ} \mathrm{C}$ for 2 h.

\section{Optimisation of reaction conditions}

To optimise LAMP assay conditions, a reaction mixture as described above was used. The reaction conditions were determined as follows: an incubation gradient spanning $60{ }^{\circ} \mathrm{C}$ to $66^{\circ} \mathrm{C}$ for $1 \mathrm{~h}$, and then at each of the optimum incubation temperatures for $30,45,60$, and 90 min, respectively as then terminated at $80^{\circ} \mathrm{C}$ for 2 min. In all, $5 \mu \mathrm{L}$ of LAMP products were analysed using $15 \mathrm{~g} / \mathrm{L}$ agarose gel electrophoresis.

\section{Sensitivity of RVFV RT-LAMP}

Using the optimum reaction system and conditions determined above, a 10-fold serial dilution of the recombinant plasmids constructed 
here was used as a template after being assessed by ND-1000 ultraviolet spectrophotometer (Nano Drop Co., Ltd, USA), and compared with the RT-PCR detection method established in the literature [13].

\section{Specificity of RVFV RT-LAMP}

The specificity of the RT-LAMP was assessed by comparing the recombinant plasmids constructed to the Peste des petits ruminants virus, Epidemic encephalitis B virus, Pasteurella multocida, E. coli, and Salmonella isolated from goats, and to a normal tissue sample also taken from goats. DNA templates were extracted using phenolchloroform method [12] which involves: taking 1 $\mathrm{mL}$ bacteria cultures and boiling them for $5 \mathrm{~min}$, centrifuging at $4,000 \mathrm{~g}$ for $10 \mathrm{~min}$, then collecting the upper phase of approximately $500 \mu \mathrm{L}$ and transferring it to a new tube, proteinase $\mathrm{K}(20$ $\mathrm{mg} / \mathrm{ml}) 25 \mu \mathrm{L}$ and $10 \%$ SDS $75 \mu \mathrm{L}$ were added, and the solution incubated at $55^{\circ} \mathrm{C}$ for $1 \mathrm{~h}$; then $800 \mu \mathrm{L}$ tris-phenol was added by mixing the extracts and inverting 10 times, spinning at $4{ }^{\circ} \mathrm{C}$ and $12,000 \mathrm{~g}$ for $5 \mathrm{~min}$, then collecting the upper phase of about $400 \mu \mathrm{L}$ and transferring it to a new tube before adding $300 \mu \mathrm{L}$ tris-phenol and $300 \mu \mathrm{L}$ chloroform and mixing, spinning at $4{ }^{\circ} \mathrm{C}$ and $12,000 \mathrm{~g}$ for $5 \mathrm{~min}$, then collecting the upper phase of about $400 \mu \mathrm{L}$ and transferring it to a new tube before adding the same volume of chloroform and mixing, spinning at $4{ }^{\circ} \mathrm{C}$ and $12,000 \mathrm{~g}$ for $5 \mathrm{~min}$, then collecting the upper phase of about $300 \mu \mathrm{L}$ and transferring it to a new tube; adding $1 / 10$ volumes of $3 \mathrm{~mol} / \mathrm{L}$ sodium acetate ( $\mathrm{pH} 5.3)$ and 2 volumes of absolute ethanol, mixing the solution to precipitate total DNA, putting the tube on ice for $30 \mathrm{~min}$, spinning at $4^{\circ} \mathrm{C}$ and $12,000 \mathrm{~g}$ for $15 \mathrm{~min}$, and slowly discarding the upper phase so as to retain the DNA precipitate; rinsing the DNA precipitate with $70 \%$ ethanol, and air-drying it in the old tube before adding $40 \mu \mathrm{L} \mathrm{ddH}_{2} \mathrm{O}$ to dissolve the DNA before storing it at $-20^{\circ} \mathrm{C}$. The RNA extraction of the virus and the normal tissue sample, and the RT reaction were subsequently performed by using the RNAiso Plus reagent (BK1501) and Primerscript $\mathrm{RT}$ reagent Kit (BK1901).

\section{RESULTS}

\section{Synthesis of the RVFV S segment gene sequence}

A DNA fragment containing approximately 288 bp was amplified using overlapping PCR (see Fig. 1, Lane 1). This target fragment was cloned into a pMD19-T vector, and the recombinant plasmid was identified by two types of PCR method and sequencing analysis. The results showed that the PCR products of the recombinant plasmid from the pMD19-T vector and usual primers (M13-RV, or M13-M4) measured $444 \mathrm{bp}$, about $156 \mathrm{bp}$ longer than the PCR products formed when using the special primers (P1 or P2) (see Fig. 1, Lanes 2 and 3). This was indicative of the recombinant plasmid having been constructed, and blast analysis of the sequencing result of the target DNA fragment of RVFV (see Fig. 2) revealed that it had a $100 \%$ homology with the reference sequence (HE687307) published in GenBank. The constructed recombinant plasmid was named pMD19-T-RS. The results indicated that the target DNA fragment of 288 bp-length of RVFV S segment gene sequence was successfully synthesised in vitro.

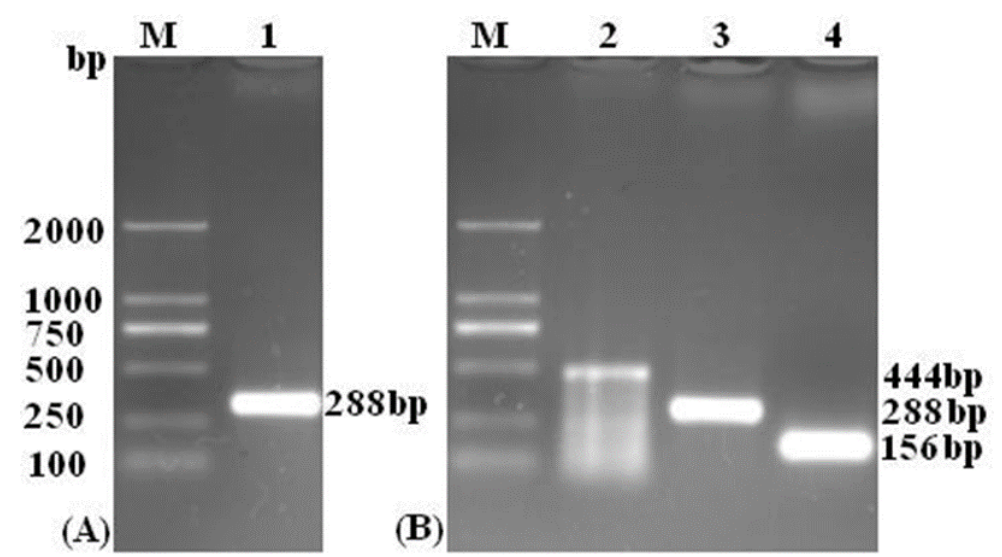

Figure 1: Artificial synthesis and identification of RVFV conserved segment $S$ gene fragment. (A) Overlapping PCR results for the RVFV conserved segment S gene fragment; (B) PCR identification results of recombined plasmid; M.DL2000 DNA marker; 1 = The overlapping PCR product of the RVFV target gene fragment; $2=$ PCR (M13-RV/M13-M4) identification product of pMD19-T-RS: 3 = PCR (P1/P2) identification product of pMD19-T-RS; 4 = PCR (M13-RV/M13-M4) identification product of pMD19-T vector 


\begin{abstract}
ACGAT TACCATCGTCCTAGTCACGAGGTTCGCT
TGCGAT T T TCTGAT T TCTACAATGTCGGAGAAT T CCCATACCGAGTCGGACT TGGAGACT TTGCATC AAACGTTGCACCTCCACCAGCAAAGCCTTTCCA GAGACT TAT TGATCTAATAGGCCATATGACTCTTA GTGAT T TCACAAGGT TCCCCAATCTAAAAGAAG CCATATCCTGGCCTCTTGGAGAACCCTCACTAGC TTTCTTTGACCTAAGCTCTACTAGAGTGCACAGG AATGAT GACAT TAGAAGGGATCAGAAAT CTCT
\end{abstract}

Figure 2: Sequencing result for the artificial target fragment

\section{RVFV basic RT-LAMP reaction}

A basic LAMP assay was carried out using pMD19-T-RS as a template: it was incubated at $64^{\circ} \mathrm{C}$ for $1 \mathrm{~h}$, and then the amplification products were analysed by agarose gel electrophoresis, enzyme-digestion and visual inspection as described earlier. The results (see Fig. 3) showed the target template was amplified with ladder-like pattern bands from about $120 \mathrm{bp}$ on the gel (Fig. 3(A), Lane 1), for which specificity was confirmed by the digestion products measuring 198 bp with EcoR I (Fig. 3(A), Lane 3). The positive reaction could also be visualised by the white precipitate of magnesium pyrophosphate (Fig. 3(B), Tube 1) and the green colour produced after the addition of diluted Supper SYBR, while the PMD-19T vector template control reactions were unamplified and evinced no visible change (Fig. 3, Lane 2 and Tube 2).

\section{Optimisation of RVFV RT-LAMP reaction conditions}

The pMD19-T-RS was used as a template to determine the RT-LAMP reaction conditions. The results (shown in Fig. 4) showed that reaction products present in Lane 1 to Lane 4 (60-62.7 ${ }^{\circ} \mathrm{C}$ ) and Lane 8 to Lane 10 (45 $\mathrm{min}, 60 \mathrm{~min}$ and $80 \mathrm{~min})$ are separately presented in a greater quantity than in the Lane 5 and Lane 6 (64.3 $65.6^{\circ} \mathrm{C}$ ) and Lane 7 (30 min).

The results indicated that the optimum LAMP conditions for a $25 \mu \mathrm{L}$ reaction volume were 63 ${ }^{\circ} \mathrm{C}$ for $45 \mathrm{~min}$ in order to create a high specificity and amplification efficiency: the optimum RT reaction should be the same as outlined in the instructions to the Primerscript RT reagent kit.

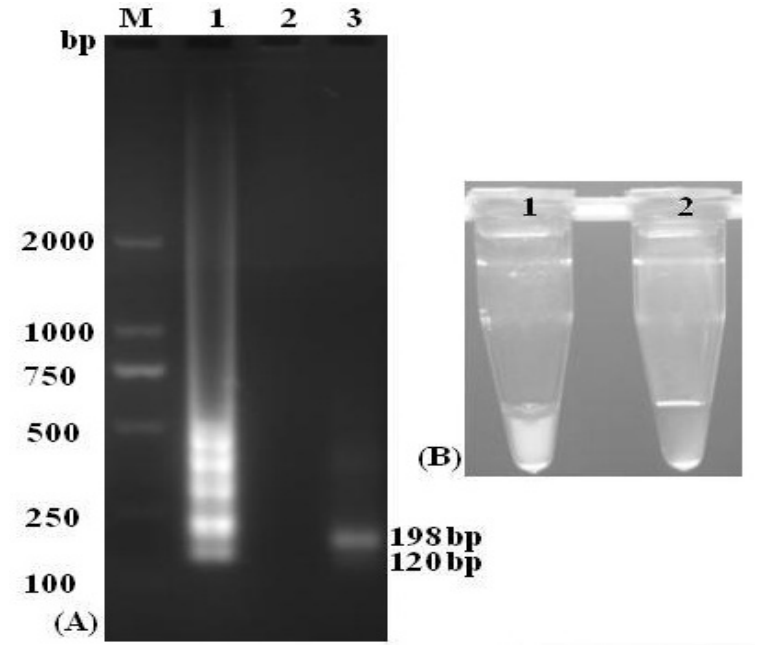

Figure 3: RVFV basic RT-LAMP results. $A=$ Agarose gel electrophoresis analysis; $B=$ Visual inspection of turbidity; $\mathrm{C}=$ Visual inspection after adding SYBR Green I; M. DL2000 DNA marker; 1 = pMD19-T-RS LAMP products, 2 = pMD-19T vector Negative Control products; 3 = product from pMD19-T-RS LAMP products digested by EcoR I

\section{Sensitivity and specificity of RVFV RT-LAMP}

The sensitivity and specificity of the RVFV RTLAMP were assessed in the tests described earlier. There was evidence of the expected ladder-like pattern of electrophoretic bands from about 120 bp (see Fig. 5, Lane 4) when almost 70 target copies (pMD19-T-RS) were detected by LAMP, which was 10 times more than with PCR (see Fig. 5, Lane 10). For the specificity, there was evidence of the anticipated ladder-like pattern in the electrophoretic bands that was only observed with pMD19-T-RS detection: no specific amplification products were obtained for the detection of the Peste des petits ruminants virus, Epidemic encephalitis B virus, E. coli, Pasteurella multocida, or Salmonella.

Trop J Pharm Res, December 2015; 14(12): 2197 


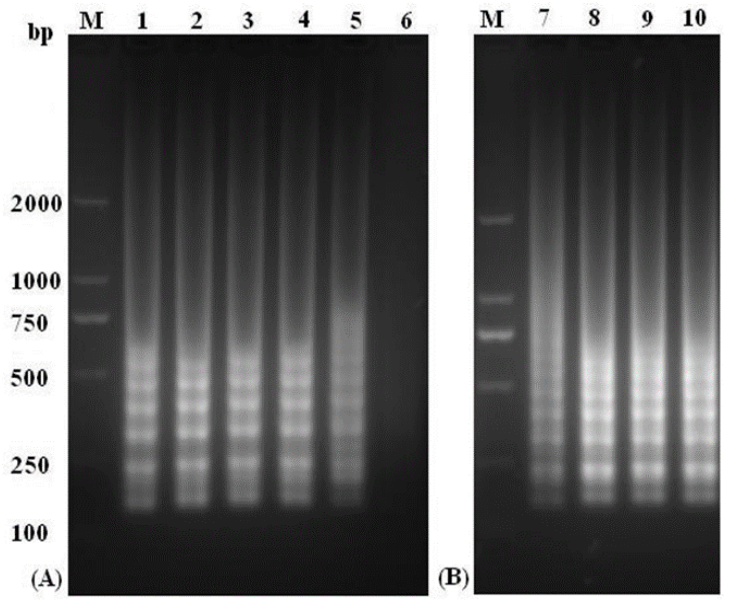

Figure 4: The optimisation RVFV RT-LAMP reaction conditions: $A=$ Reaction temperature optimisation assay; $\mathrm{B}=$ Reaction time optimisation assay; $\mathrm{M}=$ DL2000 DNA marker; 1 to 6 denote: $60,60.5,61.4$, $62.7,64.3$, and $65.6{ }^{\circ} \mathrm{C}$, respectively; 7 to 10 denote $30,45,60$, and $80 \mathrm{~min}$, respectively

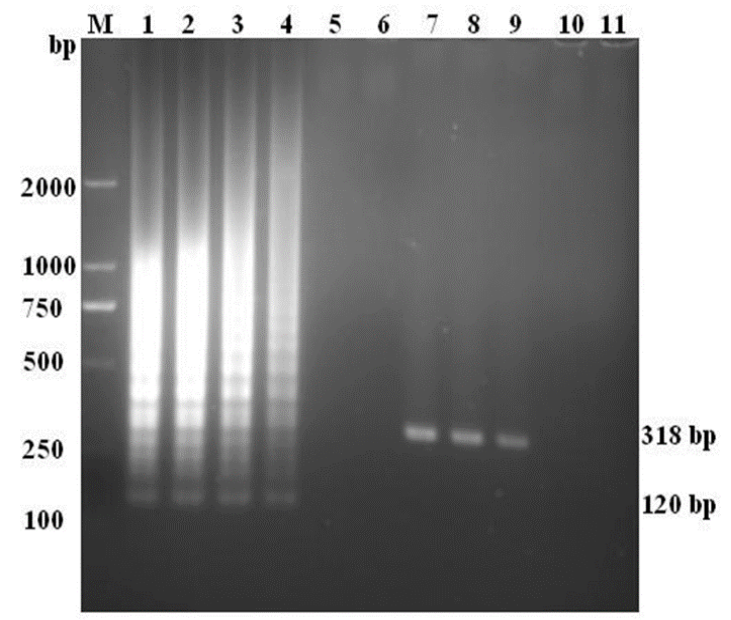

Figure 5: Sensitivity assay results of RVFV RT-LAMP on agarose gel electrophoresis. M: DL2000 DNA marker; 1 = 70,000 copies; $2=7000$ copies; $3=700$ copies; 4 = 70 copies; $5=7$ copies; $6: 8=$ Negative Control; 7 to 11 denote the RT-PCR products of $70,000,7,000,700,70$, and 7 copies of target DNA fragments, respectively

\section{DISCUSSION}

RVFV, as a mosquito-borne virus for a multitude of animals, is spread in many ways. It has caused heavy economic losses for the ruminant cultivation industry in the epidemic areas in Africa and the Middle East. Furthermore, RVFV is a serious threat to human health due to food safety problems [1]. As there is no ideal vaccine, developing a rapid detection and diagnosis technology has important agricultural and public health significance for RVFV control in both epidemic and non-epidemic areas [14]. Presently, apart from traditional methods such as virus isolation, serology diagnosis, virus neutralization testing, and hemagglutination inhibition tests, there are also RT-PCR [15], ELISA [2], nested RT-PCR [16], fluorescence RT-PCR [3], and RT-LAMP [17] technologies available for detecting and diagnosing RVFV. As there is no RVFV pathogen in China, because of the pathogen's characteristics (such as being harmful to both human and animals, and its high transmissibility, pathogenicity, and perniciousness), research on RVFV is seldom reported in China [18].

Overlap PCR technology, an important in vitro gene synthesis bioengineering technology, can synthesize overlap primers based on existing gene sequences and obtain target gene fragments using overlap extension and PCR. It has been applied in studies of molecular biology areas including molecular biological diagnosis in the case of lesser pathogens and avoiding the spread of high risk pathogens [19]. By collecting and analyzing a large number of RVFV gene sequences, nine overlap PCR primers were synthesized. Based on the primers, $288 \mathrm{bp}$ of segments from the conserved region of the nonstructural protein gene of the $S$ segment of RVFV were successfully synthesized. This was achieved by performing overlap extension reactions, PCR amplification, purification, connection, and transformation of the PCR products, followed by identification, sequencing, and analysis of the objective gene fragments. The process provides safe biomaterials for further detection methods (PCR, LAMP, Real time PCR, and multiplex PCR).

Research on RVFV detection in China is mainly based on the fluorescence RT-PCR method [18]. The LAMP method is rarely reported. LAMP detection not only presents specificity and sensitivity that is equal to or better than that of fluorescence PCR, but is also quicker and has lower requirements for producing results, reading, and judging. Owing to these advantages, LAMP has great laboratory and clinical generalization potential [11]. However, the high specificity, reaction characteristics, and primer design requirements limit the application of LAMP in the detection of some pathogenic genes. This is because simply using the default parameters in software such as Primer fails to screen appropriate primer pairs when inputting the conserved gene segments [12].

By comparing gene sequences from the $S$ segments of more than 20 strains of RVFV in the primer design process, the conserved objective 
segments were selected and 4 reasonable LAMP experimental primers were screened and synthesized. Meanwhile, degenerate bases were used in the primer syntheses to resolve the differences between gene sequences and gene mutations in the different strains. Using the synthesized gene segments as templates and optimizing the reaction temperature and time, specificity and sensitivity tests were used to detect and evaluate the operational efficiency of the LAMP primers. The results showed that RTLAMP detection of RVFV using the synthesized primers exhibits favorable specificity and sensitivity, the detection limit corresponding to 70 copies of objective gene segments. There were no signs indicating the amplification of common pathogens such as Peste des petits ruminant's virus, Epidemic encephalitis B virus, pasteurella, Escherichia coli, and Salmonella. Considering that there is no RVFV in China, and in the light of the specificity of RVFV and the strict requirements for pathogen operation, the feasibility and reliability of the constructed method were not verified by detecting RVFV pathogens. As a reference, however, in an artificial synthesis of the genes, the objected gene segments were amplified inside the gene segments using the proposed method [16]. On this basis, a theoretical basis for, and a guarantee of the reliability of, the method were provided in terms of extraction of RVFV gene groups in pathogen detection and the correct acquisition of cDNA of the objective gene segments in the RT process.

\section{CONCLUSION}

The developed RT-LAMP assay provides a rapid method for RVFV detection with high sensitivity and good specificity. It can, therefore, serve as a back-up technique for the prevention of RVFV spread as well as its control.

\section{ACKNOWLEDGEMENT}

This study was supported by grants from The Twelfth Five-year-Plan in National Science and Technology for Rural Development in China (no. 2013BAD12B04), and "211-Projects" Shuangzhi Plan in Sichuan Agricultural University, Programme for Changjiang Scholars and Innovative Research Teams in Universities (PCSIRT) IRT0848.

\section{REFERENCES}

1. Caroline AL, Powell DS, Bethel LM, Oury TD, Reed DS, Hartman AL. Broad spectrum antiviral activity of favipiravir (T-705): protection from highly lethal inhalational rift valley Fever. PLoS Negl Trop Dis 2014; 8(4): e2790.

2. Fukushi S, Nakauchi M, Mizutani T, Saijo M, Kurane I, Morikawa S. Antigen-capture ELISA for the detection of Rift Valley fever virus nucleoprotein using new monoclonal antibodies. J Virol Methods 2012; 180: 68-74.

3. Wilson WC, Romito $M$, Jasperson $D C$, Weingartl $H$, Binepal YS, Maluleke MR, Wallace DB, van Vuren PJ, Paweska JT. Development of a Rift Valley fever real-time $R T-P C R$ assay that can detect all three genome segments. J Virol Methods 2013; 193: 426431.

4. Maquart M, Temmam S, Héraud JM, Leparc-Goffart I, Cêtre-Sossah C, Dellagi K, Cardinale E, Pascalis $H$. Development of real-time RT-PCR for the detection of low concentrations of Rift Valley fever virus. $J$ Virol Methods 2014; 195: 92-99.

5. Kortekaas J. One Health approach to Rift Valley fever vaccine development. Antiviral Res 2014; 106: 24-32.

6. Gerdes GH. Rift Valley fever. Rev Sci Tech 2004; 23: 613-623.

7. Turell MJ, Linthicum KJ, Patrican LA, Davies FG, Kairo A, Bailey CL. Vector competence of selected African mosquito (Diptera: Culicidae) species for Rift Valley fever virus. J Med Entomol 2008; 45: 102-108.

8. Fischer EA, Boender GJ, Nodelijk G, de Koeijer AA, van Roermund HJ. The transmission potential of Rift Valley fever virus among livestock in the Netherlands: A modelling study. Vet Res 2013; 44: 58.

9. Iranpour M, Turell MJ, Lindsay LR. Potential for Canadian mosquitoes to transmit rift valley fever virus. $J$ Am Mosq Control Assoc 2011; 27: 363-369.

10. Turell MJ, Britch SC, Aldridge RL, Kline DL, Boohene C, Linthicum KJ. Potential for mosquitoes (Diptera: Culicidae) from Florida to transmit Rift valley fever virus. J Med Entomol 2013; 50: 1111-1117.

11. Notomi $T$, Okayama $H$, Masubuchi $H$, Yonekawa $T$, Watanabe K, Amino N, Hase T. Loop-mediated isothermal amplification of DNA. Nucl Acids Res 2000; 28 (12): E63.

12. Yang $Z$, Hou $Y$, Zeng $H$, Yao $X$, Wang $Y$, Liu H, Liu B, Wu $X$, Peng B. Development and Application of LAMP Method for Porcine Circovirus type2 Detection, Chinese Vet Sci 2014; 44: 152-158.

13. Yang Z, Wang B, Xu Q, Yao X, Zhu L, Xu Z, Wang $K, L i$ G, Peng S, Wang Y. Designment and Evaluation of the Primers for Rift Valley Fever (RVF) Virus RTPCR Detection. Adv Mater Res 2014; 989-994: 11151119.

14. Martin $V$, Chevalier $V$, Ceccato $P$, Anyamba $A$, De Simone L, Lubroth J, de La Rocque S, Domenech J. The impact of climate change on the epidemiology and control of Rift Valley fever. Rev Sci Tech 2008; 27: 413-426.

15. Ibrahim MS, Turell MT, Knauert FK, Lofts RS. Detection of Rift Valley fever virus in mosquitoes by RT-PCR. Mol Cell Probes 1997; 11: 49-53.

Trop J Pharm Res, December 2015; 14(12): 2199 
16. Sall $A A$, Thonnon J, Sene $O K$, Fall $A$, Ndiaye $M$, Baudez $B$, Mathiot $C$, Bouloy M. Single-tube and nested reverse transcriptase-polymerase chain reaction for detection of Rift Valley fever virus in human and animal sera. J Virol Methods 2001; 91: 85-92.

17. Le Roux CA, Kubo T, Grobbelaar AA, van Vuren PJ, Weyer J, Nel LH, Swanepoel R, Morita K, Paweska JT. Development and evaluation of a real-time reverse transcription loop-mediated isothermal amplification assay for rapid detection of rift valley fever virus in clinical specimens. J Clin Microbiol 2009; 47: 645-651.

18. Yang ZH, Li CT, Yang Y, Bai L, Wei L, Wang J. Real-time PCR method for rapid detection of Rift Valley Fever virus. Chinese Frontier Health Quarantine 2012; 35: 145-148.

19. Han X, Lin X, Liu B, Hou Y, Huang J, Wu S, Liu J, Mei L, Jia G, Zhu Q. Simultaneously subtyping of all influenza $A$ viruses using DNA microarrays. J Virol Methods 2008; 152: 117-121. 